Historic, archived do

Do not assume content reflec scientific knowledge, policies, 



(x) 



\section{Business Information}

PRICES named in this Wholesale List apply only to orders placed by nurserymen, fiorists and dealers.

TERMS. Cash with order, unless your credit is established with us. We will however be glad to extend credit to those deserving it. If you desire credit and do not already have an account with us, send name of your bank and two firms with whom you have a credit account. We will ship C. O. D. if one-fourth amount accompanies order.

SUBSTITUTIONS. We do not substitute unless authorized to do so. Money returned if we cannot fill your order.

GUARANTEE. We guarantee our stock trut to name and will replace same or refund purchase price for any that does not prove so. We will not be liable for more than this amount.

TELL US HOW TO SHIP. Whether by freight or express and give railroad delivery if by freight.

PACKING. All goods are carefully packed in boxes or bales for which we make a charge sufficient to cover cost of material used.

THESE PRICES are in effect at this date, July 25th, 1933, and we hope to be able to hold them without change during season of Fall 1933 and Spring 1934, but should the Federal Government make such restrictions that we will have to raise them we will notify you when we acknowledge your order.

\section{PLAN TO VISIT OUR NURSERY}

We will certainly be glad to have you come and see our stock for yourself. The items listed herein are only a few specials we have. We are growing over 100 acres in nursery stock and have a very nice stock of ornamental nursery stock. We issue a regular wholesale price list and will be glad to mail you a copy on request and also to quote on your special list of wants. 


\section{Azaleas \\ And Other}

Out of the Ordinary Plants

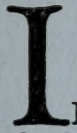

NTEREST in the Azalea has increased very much during the past few years. It is not unusual to hear of individual nurserymen growing up to 100,000 , and some are growing even more.

The public is just beginning to appreciate the beauty of them. In brilliancy, range of coloring and variety of both plant and fiower forms they excel most all other plants we have; they are among the very first flowers to bloom in spring or even late winter and with a selection of varieties we may have bloom until July. They are also one of the best plants for forcing. Many of them are evergreen and the foliage is attractive even when the plants are not in bloom.

We have found them as easy to grow as many other plants; their main requirements are a good mulch and plenty of moisture.

They are easy to sell as they can be safely moved even when in full bloom. This is very much in their favor as their bloom is the best salesman one can have. They are repeat sellers.

Quantity growing means we can grow them much cheaper than formerly and we are passing this saving on to you in better stock and lower prices. 


\section{Kurume Azaleas}

The Kurume Azaleas have been known to America only about 15 years, but in that time they have made wonderful progress as hardly a garden but what has one or more varieties of this wonderful type of Azaleas. They are also well adapted to forcing-thousands of them being sold for Mother's Day, Easter and Decoration Day. They are comparatively easy to grow and they make such a wonderful display that the demand is continually increasing. Many of the varieties are hardy out of doors as far north as Long Island. They are extremely floriferous, and in season the blossoms often completely hide the leaves. The colors are of almost every hue and shade as you will find below.

Varieties with an asterisk * are the hose-in-hose or double type..

AMOENA.* Flowers rosy purple, in dense masses. Hardy and early flowering. The foliage assumes a pleasing bronze tint in the fall and winter months.

AMOENA COCCINEA.* A new hardy Azalea, equally as hardy as Amoena while in coloring it is a brilliant fiery red. One authority thinks it will displace Hinodegiri as it becomes better known, both as an outdoor plant as well as for forcing.

AMOENA SUPERBA.* Flowers rich dark purple, bicolored with red. Leaves small, dark green, glossy.

APPLE BLOSSOM. White shaded pink, with light center. Leaves are a glossy green.

AVALANCHE. Pure white flowers of good size in large clusters. Foliage dark green, shiny.

BENIGIRI. Flowers bright deep red. Compact grower with narrow leaves.

BRIDESMAID. Glowing salmon-pink flowers produced in large clusters. Small glossy green foliage.

BOUQUET ROSE. Flowers of medium size, of a rosepink shade, darker towards center. Bronze green foliage. 
CARMINE PRINCE.* Carmine red, somewhat late in flowering, medium and compact grower.

CATTLEYA.* A delicately lilac-tinted white, shading at edges to mauve-pink.

CHARLES ENCKE. Light pink, large flowers. A good forcer. Strong healthy grower.

CHEERFULNESS. Dark vermillion-red at center, shading lighter at edge of petals. A strong growing plant with glossy green foliage.

CHERRY BLOSSOM.* Dainty light pink blossoms, shading lighter at center. Large dark green foliage.

CHRISTMAS CHEER.* The blossoms are a brilliant bright red, the foliage is very dark green and compact. The earliest of the red Kurumes.

CORAL BELLS.* Beautiful shell-pink shading somewhat deeper at center. Free flowering and dainty. Small foliage. An early bloomer.

DAPHNE. White inside with light lavender edges. A compact but slow grower.

DAYBREAK. Pure light pink flowers in dense clusters. Free flowering. Beautiful green foliage.

DELICATISSIMA. White tinged or shaded pinkishlilac with brown blotch. Dark glossy green foiage.

EXQUISITE. One of the taller growing Kurumes. Large salmon flowers. Good glossy green foliage.

FLAME. Bright madder-red flowers, suffused with copper. Beautiful. One of the best Kurumes.

HEXE.*.(Firefly). Flowers of large size, crimson-red in color. A compact grower. Good for forcing.

HINODEGIRI. Flowers brilliant scarlet, foliage rounded and deep green. The flowers are produced so profusely as to completely cover the plant. Probably the most popular Azalea grown.

HINOMAYO. Flowers a beautiful soft pink. Resembles Hinodegiri in habit of growth but leaves are smaller in size and a lighter green. Very good. 
HORTENSIA. Soft pink flowers, produced in large trusses.

J. T. LOVETT. A gorgeous late blooming variety, producing vast quantities of extra large bright pink flowers. For a late variety we recommend this one.

KIMNAZOI. Large deep red flowers; petals and leaves very narrow. This is entirely different from any other Azalea we have ever seen.

KIRISHIMA (Damask Rose). This is a rare and attractive plant for spring bloom. During May it bears large white flowers with pale scarlet center.

LAVENDER QUEEN. A fine shade of light lavender. Very free flowering. Large dark green leaves.

LORRAINE. Semi-double, deep rose. Large flowers. This is a good forcing variety.

MACRAN'THA. A salmon-red resembling Hinodegiri but about a month later. Glossy dark green foliage.

MACRANTHA FL.-PL.* Large salmon-red flowers. Good grower. Late.

MAUVE BEAUTY. The medium sized flowers are freely produced. The flowers completely cover the plant when in bloom.

MORNING GLOW. Bright rose-pink, striped and blotched darker toward center. Glossy green foliage.

MAXWELLI. Flowers large, carmine-red. Broad compact grower, hardy. The true variety is scarce.

ORANGE BEAUTY. Very large, beautiful orange-pink flowers in great clusters.

PEACH BLOW. A fine Azalea with flowers a light shade of peach-blossom-pink. Tall grower.

PINK PEARL.* A beautiful salmon-rose, shading lighter to the center. Produced in dense clusters.

SALMONEA. Fine clear pink flowers. Very compact in habit. Late. Flowers large. 
SALMON BEAUTY.* Large flowers of a beautiful shade of salmon-pink. Foliage light green.

SALMON QUEEN.* An exceptionally fine shade of salmon-pink with large individual flowers. Light green foliage.

SNOW.* Probably the best of the white Kurumes. Very free flowering. A compact grower.

SUNSTAR. Dark rose-pink with carmine stripe. A small, dainty flower.

SWEET BRIER. Dreer, the introducer says "it is one of the hardiest of the Kurumes, and of a most attractive lively eglantine rose-pink.

VESUVIUS. Brilliant salmon-red with darker biotch in center. Dark glossy green foliage.

YAYEGIRI.* Beautiful salmon-red. Narrow intense green foliage. Very showy and attractive.

\section{Azaleas Not Listed}

We are specializing in the growing of Azaleas and have many varieties not listed herein, mostly in small quantities. We have about twenty varieties of the Indica Azaleas which we are using to test their hardiness in this section. Our land is especially well adapted to the culture of this plant and we are having wonderful success in growing them.

If you want varieties not listed herein let us know what you want and if we do not have them we may be able to tell you where you may secure them.

We would certainly be glad to have you come and see just what we have and are doing with the Azalea. Whether you buy anything or not you are welcome.

We are also growing a large stock of other Nursery stock, over 100 acres, and if you are in need of any of this stock we will be glad to send you our latest Wholesale Price List and also to quote on your list of wants.

We are located on the Eastern Shore of Maryland, about 100 miles south of Wilmington, Del. (take U. S. Route No. 13) and can be reached by good roads from all directions. A road map sent on request. 


\section{Kaempferi Hybrid Azaleas}

In these new Kaempleri Hybrids-the result of crossing Kaempferi and Malvatica-there has been obtained the hardiest type of evergreen Azalea, with a good range of form and color in the flowers so far achieved. Several years tests have demonstrated that these new Hybrids are just as hardy as Kaempferi. until now the hardiest of the evergreen sorts.

ALICE. A large brilliant orange-red.

BETTY. Brilliant crimson-pink.

CARMEN. Carmine-rose.

CLEOPATRA. Light lilac-rose.

FEDORA. Deep salmon-rose.

GRAETCHEN. A wonderfully distinct and beautifully clear mauve.

KATHLEEN. Very large deep rosy-pink.

LOUISE. Light rose.

MARY. Very distinct deep pink of large size.

OTHELLO. Hinodegiri brick-red.

PURPLE KING. A good purple. Good grower.

WILLY. A fine large flower of pure clear soft pink.

ZAMPA. Strawberry-red.

\section{PRICES KAEMPFERI HYBRID AZALEAS}

1 year plants XX trans. .......... \$10.00 per 100

2 year plants XX trans. ............. 15.00 per 100

\section{AS GOOD AS CAN BE GROWN}

We are exerting every effort to produce the very best stock that can be grown, and in our trenty-seven year's experience we believe we have never offered bigger values than we are offering this season. Te feel sure that you will be more than pleased with the stock we send you. We value your friendship and orders, and will do our utmost to keep your good will. We beliere you will find our stock as good as you can get anywhere, regardless of the price you may pay. 


\section{New U. S. D. A. Azaleas}

The following new Azaleas were developed by the United States Department of Agriculture and we were one of the propagators selected by them to introduce them to the trade. They have all the appearance of being really good and are hardy out of doors in this section. They are wonderful growers. Get some of these new Azaleas and have something new to offer your trade.

BENI KIRISHIMA-No. 77113. (Rho. Indicum). Good growing large flowered pink.

MRS. CARMUCHAEL-No. 78381. An old English hybrid. Pink flowers; strong grower.

OSAKAZUKI-No. 77094. (Rho. Indicum). A large, rose-pink flower.

SATSUKI-No. 77087. (Rho. Indicum). Thulite pink with a dark blotch. Good.

SATSUKI-No. 77145. (Rho. sp.). A wonderfud ground cover or rock garden Azalea. Foliage is very good but it is a shy bloomer. Large pink flowers.

SATSUKI-No. 77104. (Rho. Indicum). Flowers large, pink. Good grower.

TAMA-NO-ITO-No. 77107. (Rho. sp.). Light rosaline purple; possibly a garden hybrid; foliage very dark green. The growth somewhat resembles $R$. Indicum.

WARAIGISHI-No. 77132. (Rho. sp.). Of the general type of $R$. Indicum but the growth is free and erect. The flowers are a deep rose pink.

YOZAKURA-No. 77096. (Rho. Obtusum Japonicum). Foliage somewhat like a Kurume but with large rose-purple flowers 2 inches in diameter.

\section{PRICES OF ABOVE AZALEAS}

2 inch pot plants .............\$6.00 per 100

1 year plants $\mathrm{XX}$ trans. ................. 10.00 per 100

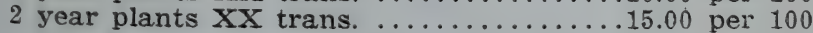

We can furnish above in thousand lots. Ask for prices in lots of 1000 or more. 


\section{Miscellaneous Azaleas}

In the following list of Azaleas you will find many species. These are not classified or separated as to their different species but we hope to have this information as complete as possible for publication at a later time. We are trying to give such descriptions that you may know, or have a general idea what each variety is.

ALTACLARENCE. A very fine large flower of intense brilliant yellow.

CALENDULACEA. The flaming color of the flowers is unequaled by any other spring flowering plant. The colors run from light salmon to deep golden orange and scarlet and usually appear before the foliage is fully developed, the latter part of May and early June.

DAHURICA. A very hardy Azalea with rosy purple flowers an inch across. Yery early flowering.

DilatatUM. - Al bery beautiful Azalea. Bright deep rose flowers in spring. Blooms early in spring before the leaves appear, covering the entire plant.

GANDAVENSIS (Ghent Hybrids). A very satisfactory type of Azalea, including a wide range of colors from white to flaming orange. They grow and thrive with a minimum of care and the shades of yellow, copper and gold are particularly lovely.

HUGO HARDYZER. (Mollis $\mathrm{x}$ Sinensis). Brilliant deep scarlet. Hardy.

INDICA ALBA (Ledifolia Alba). Very large white flowers. Good grower and a profuse bloomer.

INDICA ROSEA (Magnifica). Similar to Indica Alba excepting the flowers are rose colored.

JAPONICA. A vigorous shrub, growing up to six feet and hardy in New England. The flowers are orangered or flaming red. Makes a wonderful display.

J. C. VAN TOL. Clear, vivid red flowers of the Mollis type. Deciduous.

KAEMPFERI. Large, beạtififul red flowers. Hardy; tall and bushy. 
MISS LOUISA HUNNEWELL. A cross between Mollis and Japonica. Salmon-yellow shading to salmon. A very beautiful, hardy variety.

MOLLIS. The golden-yellow flowers appear before the leaves in early spring. Deciduous. Forces well.

MOLLIS x SINENSIS. Mixed hybrids ranging in color from light yellow to brilliant deep scarlet.

MUCRONULATA. Large rose-lavender flowers. One of the earliest to bloom. Hardy in New England. Deciduous.

NUDIFLORA. (Pinxterbloom). Flowers very fragrant, light pink striped with white, sometimes light pink striped with red. A native plant and generally known as "Wild Honeysuckle."

OCCIDENTALIS. A native of the West Coast. Produces masses of white to light pink blossoms marked with yellow on the upper parts.

PONTICA (Lutea). A broad, densely branched, deciduous Azalea. Large, yellow, fragrant flowers are produced in clusters at the end of the branches before the leaves appear.

POUKHANENSIS. The rose-pink to rose-purple, fragrant flowers are produced abundantly in early spring. Deciduous, low, spreading habit. Hardy in New England.

RHOMBICA. A tall growing Japanese Azalea with rose-purple flowers an inch and a half to two inches across. Flowers in early spring before the leaves come out. Hardy.

SCHLIPPENBACHI. The flowers are sweet scented, pure bright pink, and about three inches across. In autumn the leaves turn yellow, orange and crimson before they drop. Perfectly hardy in New England.

VISCOSA (Swamp Honeysuckle). Late blooming. Grows in low, swampy soils. The flowers are pure white sometimes flushed with pink.

YODOGAWA. Purplish-pink, brilliant double. flowers in early spring. A semi-evergreen Japanese Azalea. 


\section{Price List of Azaleas}

Below we are giving the approximate quantity and price of the sizes that we can furnish of each variety that we have to offer at this date, July $25 \mathrm{th}, 1933$. We have more than one hundred thousand cuttings of these varieties and will have a larger quantity of the 2 inch pot size to offer as soon as they make sufficient growth to send out. If you are interested in rooted cuttings let us have your list for quotations.

\section{Kurume Azaleas}

\begin{tabular}{|c|c|c|c|c|c|c|}
\hline & \multicolumn{2}{|c|}{2 in. pots } & \multicolumn{2}{|c|}{1 yr. trans. } & \multicolumn{2}{|c|}{$2 \mathrm{yr}$. trans. } \\
\hline & 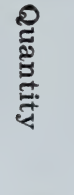 & 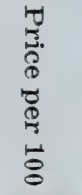 & 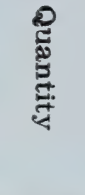 & 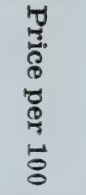 & 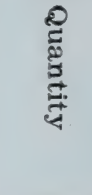 & 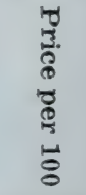 \\
\hline Amoena & 900 & $\$ 5.00$ & 1850 & $\$ 7.50$ & 5000 & $\$ 12.50$ \\
\hline Amoena Coccinea. & 500 & 6.00 & 4500 & 10.00 & 5500 & 15.00 \\
\hline Apple Blossom ... & & & 115 & 12.50 & & \\
\hline Avalanche & 50 & 10.00 & 75 & 15.00 & & \\
\hline Benigiri & 50 & 8.00 & 150 & 12.50 & 140 & 17.50 \\
\hline Bridesmaid & 575 & 7.50 & 1500 & 10.00 & 60 & 15.00 \\
\hline Bouquet Rose .... & & & 75 & 15.00 & & \\
\hline Carmine Prince .. & & & 20 & 15.00 & 50 & 20.00 \\
\hline Cattleya ........... & & & 350 & 12.50 & 50 & 17.50 \\
\hline $\begin{array}{c}\text { Chas. Encke } \ldots \ldots \\
\text { Cheerfulness }\end{array}$ & 475 & 7.50 & 1000 & 10.00 & & \\
\hline $\begin{array}{l}\text { Cheerfulness .... } \\
\text { Cherry Blossom }\end{array}$ & $\begin{array}{l}275 \\
175\end{array}$ & $\begin{array}{l}8.00 \\
8.00\end{array}$ & & & & \\
\hline $\begin{array}{l}\text { Cherry Blossom } \\
\text { Christmas Cheer }\end{array}$ & & & $\begin{array}{l}500 \\
175\end{array}$ & $\begin{array}{l}12.50 \\
12.50\end{array}$ & 50 & 17.50 \\
\hline Coral Bells ....... & 750 & 7.50 & 1200 & 10.00 & 70 & 15.00 \\
\hline Daybreak & & & 100 & 10.00 & 225 & 12.50 \\
\hline Exquisite & & & 35 & 15.00 & & \\
\hline & 600 & 7.50 & 2000 & 11.00 & 350 & 15.00 \\
\hline & 800 & 7.50 & 1800 & 11.00 & 90 & \\
\hline $\operatorname{leg} i$ & 5000 & 6.00 & 40000 & 10.00 & 30000 & 15.00 \\
\hline Hinomas & 1200 & 8.00 & 2300 & 12.50 & 625 & 17.50 \\
\hline OT & & & 35 & 15.00 & & \\
\hline J. T. Love & & & 2500 & & 500 & 15.00 \\
\hline Kimnazoi & 180 & 10.00 & 225 & 15.00 & & \\
\hline
\end{tabular}


PRICE LIST continued-Kurume Azaleas,

2 in. pots 1 yr.trans. 2 yr.trans.

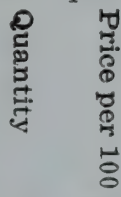

Lavender Queen .. $\quad 75 \quad \$ 8.00$

Lorraine .......6600

Macrantha

Macrantha fl. pl. . .

Mauve Beauty .... 5

Morning Glow ....

Maxwelli ........200

Orange Beauty ...2 275

Peach Blow ......

Pink Pearl ......250

Salmonea ....... 250

Salmon Beauty ... 470

Salmon Queen .... 50

Snow .......... 45

Sunstar ........ 85

Sweet Brier .....1200

Vesuvius ........ 180

Yayegiri .......... 160

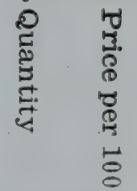

7.50

$275 \$ 12.50$

$1000 \quad 11.00$

$1000 \quad 10.00$

$\begin{array}{lll}10.00 \quad 80 & 15.00\end{array}$

$\begin{array}{ll}60 & 15.00\end{array}$

7.50

8.00

$\begin{array}{lll}400 & 12.50\end{array}$

$60 \quad 15.00$

8.00

6.00

7.50

8.00

10.00

10.00

6.00

7.50

6.00

$\begin{array}{ll}550 & 10.00\end{array}$

$1125 \quad 12.50$

$100 \quad 12.50$

$\begin{array}{ll}750 & 15.00\end{array}$

$110 \quad 15.00$

$800 \quad 10.00$

$400 \quad 12.50$

$1900 \quad 10.00$

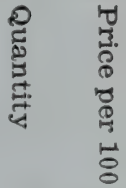

$30 \$ 15.00$

$\begin{array}{lll}100 & 15.00\end{array}$

$2500 \quad 12.50$

$100 \quad 17.50$

$\begin{array}{ll}40 & 17.50\end{array}$

$200 \quad 15.00$

$\begin{array}{ll}50 & 15.00\end{array}$
$25 \quad 20.00$

$225 \quad 15.00$

$\begin{array}{ll}60 & 17.50\end{array}$

$\begin{array}{lll}700 & 15.00\end{array}$

\section{PRICES OF SPECIMEN AZALEAS}

All our Azaleas have been carefully cutback and kept carefully trimmed and we believe are much better plants than are usually offered in the sizes we furnish.

These prices are per each. We will allow a discount of $15 \%$ on lots of ten or more of a variety and $25 \%$ on lots of one hundred or more of a variety.

$$
\begin{array}{llllll}
6-8 & 8-10 & 10-12 & 12-15 & 15-18 & 18-21
\end{array}
$$

in. in. in. in. in. in.

Amoena $\ldots \ldots \ldots \ldots \ldots . \$ 0.50 \$ 0.75 \quad \$ 0.85 \$ 1.00 \quad \$ 1.50 \$ 2.00$

$\begin{array}{lllllll}\text { Hinodegiri } \ldots \ldots \ldots \ldots & .60 & .75 & 1.00 & 1.25 & 1.50\end{array}$

Ledifolia Alba ....... $\quad .60 \quad .75 \quad 1.00$

Macranthus ..........60

Mucronulata .........

Poukhanensis .........

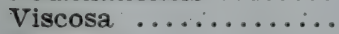

$\begin{array}{lll}.75 & 1.00 & 1.25\end{array}$

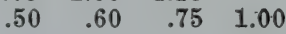

Yayegiri $\ldots \ldots \ldots \ldots \ldots \ldots .6 .60 \quad .75$ 


\section{Miscellaneous Azaleas}

These prices are per each. We will allow a discount of $15 \%$ on lots of ten or more of a variety and $25 \%$ on lots of one hundred or more of a rariety excepting Altaclarence, Miss Hunnewell, Occidentalis and Pontica, which prices are net.

$$
\begin{array}{cccccc}
\text { 6-8 } & 8-10 & 10-12 & 12-15 & 15-18 & 18-21 \\
\text { in. in. in. in. in. in. }
\end{array}
$$

Altaclarence ..........

Hugo Hardyzer $\ldots \ldots . .25$ $\$ 1.00 \$ 1.50$

Indica Alba ........... $.15 \quad .20$

Indica Rosea ........ $.15 \quad .20$

$\begin{array}{llll}\text { Japonica } & . . \ldots \ldots \ldots \ldots & .20 & .30\end{array}$

Miss Louisa Hunnewell

Mollis ...............

Occidentalis ...........

$.15 \quad .20$

Pontica

Schlippenbachi $\ldots \ldots \ldots . .15$

Yodogawa

\section{.25}

.25
1.25

1.00

1.00

\section{Two-Year Seedling Azaleas}

We have the following varieties, two years old, growing in flats that we are offering very reasonable. Here is your opportunity to get a good collection at a very small price. By growing them on a few years you can increase your investment many times. You will hardly find this collection being offered by any other grower or group of growers. Our stock of some of the varieties is limited, therefore advise ordering eariy.

Per 100

Calendulacea ......\$3.00

Dahurica ........ 2.50

Dilatata ........ 2.50

Gandavensis ........ 3.00

Taponica .......... 3.00

Kaempfori ........ 2.00

Mollis
Mollis x Sinensis ...\$3.00

Nudiflora ......... 3.50

Occidentalis .......2.50

Pontica .......... 2.50

Poukhanensis ....... 2.50

Rhombica .......2. 2.5?

Schlippenbachi ..... 3.00

We believe you will find the quality of our plants as good as you can get anywhere, regardless of the price you may pay. We want the stock we send you to merit your orders again when you need more stock. 


\section{Rhododendrons}

AMERICA. Recently imported with flowers of an unusually clear shade of red.

AMPHION. One of the most desirable varieties, with enormous trusses and splendid foliage. The flowers are clear, glistening pink with large, white centers.

CATAWBIENSE ALBUM. Flowers of pure white, and blooms the last of May or first of June. Foliage good.

DR. H. C. DRESSELHUYS. Glittering crimson flowers and trusses of unusual size. Compact grower and one of the very best reds.

24 to 30 inch plants .............\$3.50 each

EDWARD S. RAND. Rich crimson flowers with a dark eye. A very unusual variety.

EVERESTIANUM. Large trusses of frilled flowers delicately shaded with lilac pink and lightly spotted greenish black. Good foliage; compact grower.

F. D. GODMAN. A good variety for massing. Large, rich crimson blooms with dark blotch.

IGNATIUS SARGENT. Shining rose-scarlet flowers produced on exceptionally large trusses.

MRS. C. S. SARGENT. Gorgeous dark blooms of glowing pink. Distinct, wavy foliage.

PRESIDENT LINCOLN. A splendid grower and bloomer. The lilac-pink flowers, with brown eye are borne in well shaped trusses on stout stems.

30 to 36 inch plants ..........\$3.50 each

ROSEUM ELEGANS. Clear rose-pink, and in every respect an excellent Rhododendron, with lovely foliage.. Compact grower.

30 to 36 inch plants ............\$3.50 each

\section{PRICES OF ABOVE RHODODENDRONS}

We have a small lot of each of the above varieties two year old grafts about 12 inches tall that we will offer at $\$ 1.00$ each. 


\section{Native Rhododendrons}

There is always a market for good nursery grown Native Rhododendrons. We have a fine lot of two year seedlings of the three best varieties and are offering them to the trade for the first time. They will increase in vaiue very quickly.

CATAWBIENSE. The flowers are borne profusely in very large. round trusses, come in various shades of lilac-purple the early part of June.

I yr. seedlings from flats ........\$3.50 per 100

CAROLINIANTM. One of the very finest broad-leaved evergreens. Grows 4 to 6 feet tall and as much in diameter: has dark green leaves and blooms profusely. The clustered flowers are pale to deep pink. open before the young branches begin to grow and therefore are not hidden by the foliage.

$2 \mathrm{yr}$. seedlings from flats ........\$3.50 per 100

MAXIMU. Flowers rosy white to white, produced in late June. Foliage very thick, smooth, and large. U'seful for bold masses.

2 yr. seedlings from flats ......\$3 5.50 per 100

\section{Our Native Peat}

To grow Azaleas and Rhododendrons successfully you must have leaf mold, peat in some form or some similar substance. The have used Russian, German and Holland Peat, leaf mold collected from under trees in our local forests, but by far the best material we have ever used is a form of native peat. a deposit of which we have found near here. It runs from twelve to twenty four inches thich and is composed of thoroughly decayed leares, and other material in a maple swamp which has been generations in the maling. The $U$. S . Dept. of Agriculture are users of this material.

If you would like to try it we will send you a two. bushel bag for $\$ 1.00$. Will quote special prices on car. load lots or less. Try a sample bag. We helieve you will like it so well you will want more. 


\section{Holly}

AMERICAN HOLLY (Hex Opaca). We think there is nothing prettier than our native American Holly, especially when it is full of bright red berries, although its bright glossy foliage is beautiful all the year. We are offering these plants from seed and also from cuttings which were taken from berry-bearing trees. Most of these little plants from cuttings are bearing berries the second season. At the present time, Tuly $25 \mathrm{th}, 1933$, we have about 2500 of these plants from cuttings. If you want some better order early.

1 yr. seedlings $\ldots \ldots \ldots \ldots \ldots \ldots \ldots \ldots 4.00$ per 100

2 yr. pot grown from cuttings .......17.50 per 100

18 to 24 in. grafted plants .........150.00 per 100

ENGLISH HOLLY (Mex Aquifolium). This is the Holly that is being grown in the Pacific Northwest and which brings such high prices in the markets at Christmas time. The berries are a bright red and the foliage is a bright glossy green which looks as if it has been varnished. The berries are much larger than those of the American Holly. It has proven entirely hardy here, even the little one-year seedlings going safely through the winter.

1 yr. seedlings $\ldots \ldots \ldots \ldots \ldots \ldots \ldots \$ 5.00$ per 100

3 yr. seedlings grown in pots 2 yr. .. 12.50 per 100

JAPANESE HOLLY (Ilex Crenata). This is a bushy shrub, sometimes under favorable conditions it will grow possibly 20 feet tall. It has glossy, dark green, $\begin{array}{lll}\text { oval leaves and small black berries. } & 100 & 1,000\end{array}$

2 yr. seedlings $\ldots \ldots \ldots \ldots \ldots \ldots \ldots \ldots \ldots 2.00 \$ 15.00$

$21 / 4$ in. pots $3 \mathrm{yr} . \ldots \ldots \ldots \ldots \ldots \ldots \ldots \ldots \ldots \ldots, 7.50 \quad 60.00$

4 to $6 \mathrm{in.} \mathrm{XX}$ trans. .............. $6.00 \quad 50.00$

6 to 8 in. $\mathrm{XX}$ trans. .............. $7.50 \quad 60.00$

8 to 10 in. XX trans. .............. $9.00 \quad 75.00$

10 to 12 in. XX trans. ..................11.00 100.00

18 to 24 in. XXX trans. ............75.00

INKBERRY (Ilex Glabra). A very pretty native evergreen holly, low and bushy. Oval shaped leaves and an abundance of small black berries which are much liked by birds. Should be more planted.

6 to 8 in. trans. .............. $\$ 10.00$ per 100

24 to 30 in. XX trans........... 75.00 per 100 


\section{Boxwood}

We are growing large quantities of Boxwood, over a quarter million now, and are enabled to furnish it at very low prices as you will note below. This Boxwood is first-class in every way. We have customers who send us repeat orders several times during a season. We know you will like our Boxwood if you will let us send you some of it. Good Stock, Good Service, and Low Prices.

\section{SUFFRUTICOSA (old English Box)}

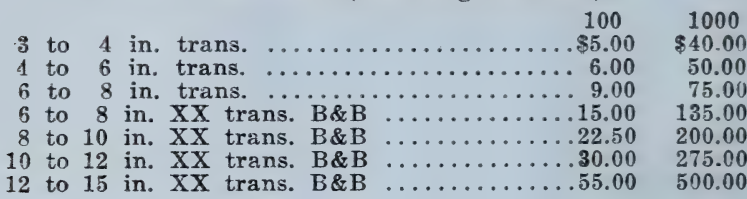

We will quote on larger sizes.

\section{SEMPERVIRENS (Bush Box)}

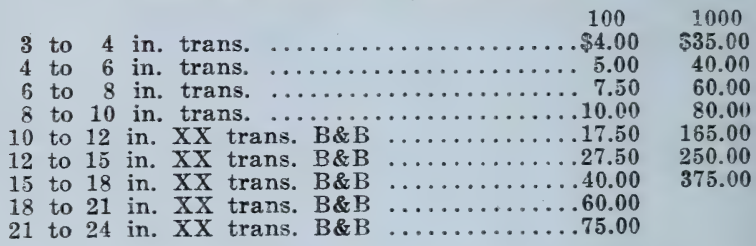

\section{MAPONICA (Japanese Box)}

Same prices and sizes as Sempervirens except only hundred lots in the $B \& B$ sizes.

\section{KOREAN (A new very hardy Box)}

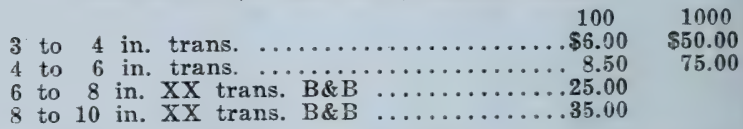

We also have Arborescens Box and Handsworthi Box. If interested let us quote you prices. 


\section{Other Good Plants}

ENGLISH IVY. A cllnging evergreen vine, extremely hardy, for use on walls, in a northern exposure or as a ground cover in shady locations.

3 yr. field grown plants ........\$6.00 per 100

3 in. pot grown plants ............. 7.50 per 100

ENKIANTHUS CAMPANULATUS. A charming ornamental shrub, with drooping racemes of short yellowish or pale orange flowers, veined darker. These with the brilliant red foliage in autumn, make this one of the handsomest shrubs for the greater part of the year. Flowers in May.

2 to $3 \mathrm{ft} . \ldots \ldots \ldots \ldots \ldots \ldots \ldots 75 \mathrm{c}$ each, $\$ 6.00$ per 10

3 to $4 \mathrm{ft}$. ............ $\$ 1.00$ each, 8.50 for 10

LEUCOTHOE CATESBAEI (Andromeda Catesbaei). A valuable shrub for planting under trees, and in other shady positions. Flowers are white and are borne in long, pendulous racemes, with a characteristic fragrance. The shining dark green foliage is evergreen and sometimes assumes brilliant bronze shades in fall.

2 yr. seedlings from flats $\ldots \ldots \ldots \ldots \$ 3.00$ per 100

MAHONIA AQUIFOLIUM (Oregon Hollygrape). Glossy green, holly-like leaves and yellow flowers in May. One of the most attractive and decorative evergreens.

1 yr. seedlings $\ldots \ldots \ldots \ldots \ldots \ldots \ldots \ldots \$ 2.00$ per 100

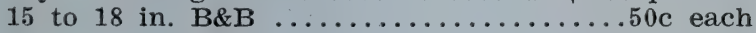
18 to 24 in. B\&B ................. each

MAgNOLIA LILIFLORA NIGRA (Purple Lily Magnolia). The flowers of this Magnolia are produced early in the spring before the leaves appear. The petals are 4 to 5 inches long forming a cup-shaped flower 5 to 8 inches in diameter, pink inside and dark purple outside. Produces flowers intermittingly all through the summer. Bushy habit of growing.

3 to $4 \mathrm{ft}$. nice bushy plants ........\$2.00 each 4 to $5 \mathrm{ft}$. nice bushy plants ........... 3.00 each 
MAGNOLIA GLAUCA (Virginiana) (Sweetbay). This is one of our native small trees and is very much in demand at the present time. We have collected and sold many thousands of these plants but are now growing them from our own collected seed. It grows 15 to 20 feet high, has bluish, glossy leaves, nearly white underneath and with us it is evergreen. Its native habitant is low, moist soils but we grow it on well drained soils where it seems to do equally as well. Produces delightfully sweet scented white cupshaped flowers 3 to 4 inches in diameter in May and June. The red fruit pods showing the scarlet seeds are also very attractive.

Nice two year plants ....................... 500 per 100 18 to 24 inch bushy plants .......6. 60.00 per 100

PACHYSANDRA TERMHNALIS (Japanese Spurge). A small evergreen ground-cover which forms a dense carpet. May be used for edging walks and beds, between evergreen shrubs or to cover the ground under dense trees where grass will not grow. It will eliminate much labor, as it needs no hoeing and will allow no weeds to grow.

1 yr. trans. ................\$3.50 per 100

$21 / 4$ in pot plants $3 \mathrm{yr}$. very nice .... 7.50 per 100

PIERIS FLORIBUNDA (Andromeda Floribunda). Low, compact, evergreen shrub with small dark green leaves. Young branches and leaf-stalks dull red and hairy. Pretty white flowers borne in small, dense, upright panicles at the ends of branches.

2 yr. seedlings from flats .......\$3.00 per 100

3 inch pots, nice plants ................ per 100

PIERIS JAPONICA (Andromeda Japonica). Not quite as compact as above. Leares narrow and toothed. Panicles of buds dull red, opening white in spring. Foliage spotted bronzy red in winter.

$2 \mathrm{yr}$. seedlings from flats. .......\$3.00 per 100

VINCA MINOR (Myrtle) (Common Periwinkle). A hand. some evergreen ground-cover with showy bright blue flowers borne freely in early spring and at intervals throughout the summer and autumn. It is perfectly. hardy and does splendidly under trees or in shady nooks where few plants will thrive.

3 yi. pot grown plants very heary ...\$7.50 per 100 


\section{Yews}

We have always thought Yews were one of the very best plants that a nurseryman could grow, both for their landscape use and for the money in growing them. You will see we have a very large collection and can furnish some varieties in lots of several thousand. If you want more than ten of a variety and size in the B\&B sizes we will be glad to quote special prices if you will tell what you want. Plant a few more this year.

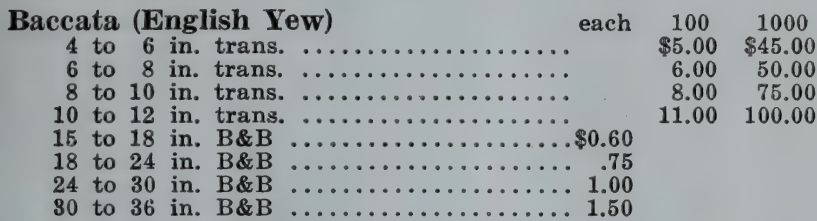

Baccata Aurea (Golden English Yew)

4 to 6 in, trans.

9 to 12 in. $\mathrm{B} \& \mathrm{~B} \ldots \ldots \ldots \ldots \ldots \ldots \ldots \ldots \ldots, \ldots 0.60$

12 to 15 in. $B \& B \ldots \ldots \ldots \ldots \ldots \ldots \ldots .80$

15 to 18 in. $B \& B \ldots \ldots \ldots \ldots \ldots \ldots \ldots \ldots \ldots \ldots \ldots .1 .00$

$\$ 7.50 \quad \$ 60.00$

Baccata Compacta (Compact English Yew)
4 to 6 in. trans.
$\$ 7.50 \quad \$ 60.00$
6 to 8 in. trans.
$8.50 \quad 75.00$
8 to 10 in. trans.
$11.00 \quad 100.00$
10 to 12 in. trans.
12.50

Baccata Elegantissima (Variegated English Yew)
4 to 6 in. trans
6 to 8 in. trans.

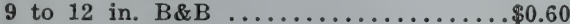
12 to 15 in. $B \& B$. .................. 80
15 to 18 in. $B \& B \ldots \ldots \ldots \ldots \ldots \ldots \ldots \ldots \ldots \ldots \ldots \ldots \ldots .1 .00$

$\$ 10.00$

12.50

Baccata Repandens (Spreading English Yew)

4 to 6 in. trans.

$\$ 7.50 \quad \$ 60.00$

6 to 8 in. trans.

$8.50 \quad 75.00$

8 to 10 in. trans.

$11.00 \quad 100.00$

10 to 12 in. trans.

12.50

9 to 12 in. B\&B ............... $\$ 0.50$

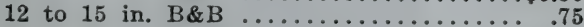

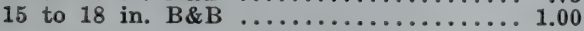

Baccata Washingtonia (Washington English Yew)

4 to 6 in. trans ................. $\$ 10.00$

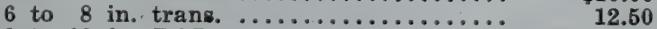

9 to 12 in. $B \& B \ldots \ldots \ldots \ldots \ldots \ldots \ldots \ldots \ldots \ldots, \$ 0.60$

12 to 15 in. $B \& B$ B..................... 80 
Baccata Overiender

8 to 10 in. trans.

each

100

1000

Baccata Hibernica (Irish Yew)

4 to 6 in. trans.

$\$ 13.50 \$ 125.00$

6 to 8 in. trans.

$16.00 \quad 150.00$

8 to 10 in. trans.

20.00

10 to 12 in. trans.

9 to 12 in. B\&B

25.00

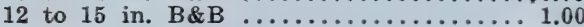

Canadensis (Ground Hemlock) (American Yew)
4 to 6 in. trans.
6 to 8 in. trans.
8 to 10 in. trans.
12 to 15 in. $B \& B$
$\$ 0.80$
15 to 18 in. $B \& B$
1.00
18 to 24 in. B\&B ................ 1.25

$\$ 7.50$

10.00

12.50

Cuspidata (Japanese Yew) Grown from cuttings
4 to 6 in. trans.
6 to 8 in. trans.
8 to 10 in. trans.
10 to 12 in. trans.
12 to 15 in. $B \& B$
15 to 18 in. B\&B
$\$ 0.75$
1.00

$\$ 5.00$

6.00

75.00

$11.00 \quad 100.00$

Cuspidata (Japanese Yew) Grown from seed

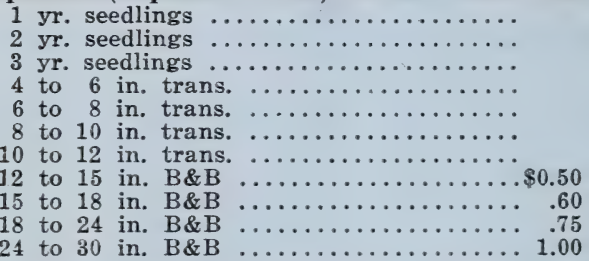

$\begin{array}{rr}\$ 1.25 & \$ 10.00 \\ 1.75 & 15.00 \\ 2.50 & 20.00 \\ 5.00 & 45.00 \\ 6.00 & 50.00 \\ 8.00 & 75.00 \\ 11.00 & 100.00\end{array}$

Cuspidata Capitata (Tree Form Japanese Yew)
4 to 6 in. trans.
6 to 8 in. trans.
8 to 10 in. trans.
10 to 12 in. trans.
$\ldots \ldots \ldots \cdots \cdots \cdots+\$ 0.50$
12 to 15 in. $B \& B$
15 to 18 in. B\&B
.75
24 to 30 in. B\&B
1.00

$\$ 5.00$

6.00

8.00

11.00

$\$ 45.00$

Cuspidata Nana (Dwarf Japanese Yew)
4 to 6 in. trans
6 to 8 in. trans.
8 to 10 in. trans.
9 to 12 in. $\mathrm{B} \& \mathrm{~B}$
12 to 15 in. B\&B

$\$ 90.00$

$12.50 \quad 115.00$

15.00 
$\begin{array}{lllllllll} & \text { each } & 100 & 1000\end{array}$

Cusp. Brevifolia Erecta (Upright Dwarf Jap. Yew)

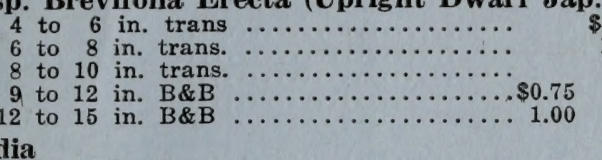

Media

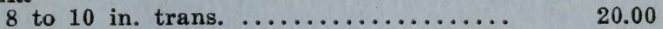

10 to 12 in. trans. ................ 25.00

Media Andersoni
4 to 6 in. trans.
$\$ 15.00$
6 to 8 in. trans.
20.00
8 to 10 in. trans.
25.00

Media Browni

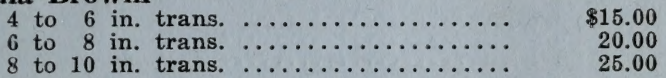

Media Hatfieldi

4 to 6 in. trans. .............. $\$ 15.00$

6 to 8 in. trans. ................. 20.00

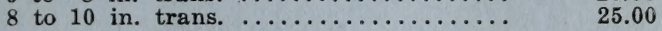

Media Hicksi

4 to 6 in. trans $\ldots \ldots \ldots \ldots \ldots \ldots \ldots \ldots$

6 to 8 in. trans. .................... 12.50

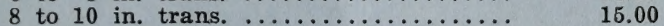

$\$ 90.00$

115.00

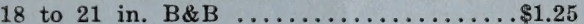

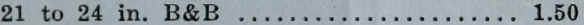

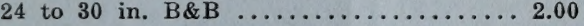

Media Wellesleyana

4 to 6 in. trans. ............. $\$ 15.00$

6 to 8 in. trans. ............... 20.00

\section{Hunnewelliana}

4 to 6 in. trans. ............. $\$ 15.00$

6 to 8 in. trans. ................. 20.00

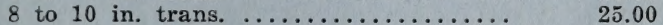

12 to 15 in. $B \& B \ldots \ldots \ldots \ldots \ldots \ldots \ldots .60$

The following varieties were grown from stock purchased from the late T. D. Hatfield and is a rare chance to get something really good in Yews. We do not know the form of growth of these Yews. They were selected as being the best of his unnamed varieties.

Media No. 6

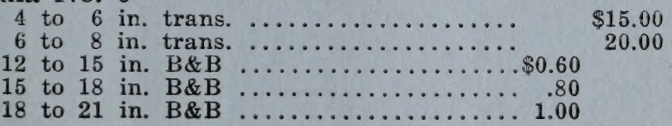


Media No. 7

4 to 6 in. trans. ................ each ${ }_{\$ 15.00}^{100} 1000$

6 to 8 in. trans.

12 to 15 in. B\&B

20.00

15 to 18 in. $B \& B$

Media No. 8

4 to 6 in

6 to 8 in trans.

12 to 15 in. $B \& B \ldots \ldots \ldots \ldots \ldots \ldots \ldots \ldots .60$

15 to 18 in. B\&B ................. 80

$\$ 15.00$

20.00

Media No. 18

4 to 6 in. trans. . . $\ldots \ldots \ldots \ldots \ldots \ldots \ldots \ldots \ldots \ldots, \$ 15.00$

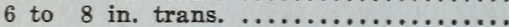

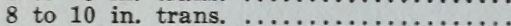

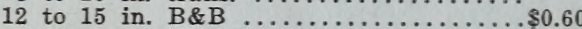

15 to 18 in. $B \& B$............................ 80

18 to 21 in. B\&B ....................... 1.00

Media No. 23

8 to 10 in. trans. $\ldots \ldots \ldots \ldots \ldots \ldots \ldots \ldots$

25.00

Media No. 24

8 to 10 in. trans.

25.00

\section{A NEW BOOK-AZALEAS AND CAMELLIAS}

By H. H. HUME

Interest in Azaleas and Camellias is greatly increasing. Until now, little information on varieties, care, and culture of these plants has been available. Mr. Hume accurately and thoroughly describes the varieties best suited for various uses and discusses questions on culture, such as soils, fertilization, planting, propagation, and general care, indoors and out. He has taken special care to describe accurately the several groups and varieties, and his suggestions on the use and culture are very practical. If you are growing Azaleas and Camellias you will find this book of much help.

Price $\$ 1.50$ postpaid.

\section{Acres Stock Not Listed}

We believe we are growing and offering one of the most complete stock of Specimen and Lining-Out stock being offered at this time. We have over 100 acres in nursery stock, and have five greenhouses devoted to propagation. We can furnish several varieties of specimen evergreens in thousand lots or more and devote about ten acres to lining-out stock alone. We issue a regular Wholesale Price List and will be glad to mail you a copy at any time.

We believe you will find our stock as good as you can get anywhere, regardless of the price you may pay. We will do our utmost to please you in every way. 
